\title{
ANALYSIS OF STUDENTS' STEM LITERACY BASED ON GENDER DIFFERENCES IN SCIENCE LEARNING
}

\author{
Annisa Nurramadhani ${ }^{\left.a^{*}\right)}$ \\ a) Pakuan University, Bogor, Indonesia \\ *) Corresponding Author: annnisanurramadhani@unpak.ac.id
}

Article history: received 29 January 2020; revised 19 February 2020; accepted 16 February 2020

\begin{abstract}
STEM literacy can be defined as an ability to identify, apply, and to integrate the concept of science, technology, engineering, and mathematics to innovate and solve the complex problem. Especially in science learning that approached by the strategies like STEM. Because this revolution industry 4.0 era, students are demand to workface in integrate to their living life. So, they are asked can solved the problem properly, giving the solution for global problem wisely. In the process of learning science with project, somehow students show their own performance. The results of project-based learning pointing the different result of performing based on gender differences. The method that is used is descriptive. The subject in this research is the student's preservice teacher of science and biology education study program for about 21 students with 4 boys and 17 girls in the second semester of the freshmen. The research is conducted in basic physic laboratory. The laboratory activity is using STEM approach with project. The students are divided into 4 groups and each group consist of boy's students. The research instrument to take the data that is used are observation sheet for student's performance in laboratory activity and questionnaire of students for their laboratory activity per-aspect that describes their competences in science, technology, engineering, and mathematics. The technique to take the data that is used in this research are video recording, observation, and informal interview. The results are student's STEM literacy has different score based on the gender differences. In the first project, sailor boat, boys reach the higher percentages in aspect science, engineering, and technology, while girls reach the higher percentages in science and technology. The second project, let's fun with music, boys reach the higher percentages in aspect science, engineering, and technology, while girls reach the higher percentages in science and engineering. In both of project, boys and girls reach the lowest percentages in mathematics aspect. But, in whole score boys has reached higher than girls. It can be concluded that boys are outperformed than girls in STEM literacy in science learning especially in basic physics laboratory activity.
\end{abstract}

Keywords: STEM literacy; science learning; gender differences; project based learning

\section{INTRODUCTION}

Commonly, science learning delivered by the method that enhance student's performance. Not only students conceptual learning, but also their affective and physicomotoric. It can be named as students cantered. The methods are inquiry-based learning, project-based learning, discovery learning, and many more. Recently, science learning should integrate for not only physic chemistry, and biology subject but also it can be integrated toward technology, mathematics, society, environment, and all problem surround the living life to contribute development of industrialized and modern society [1][2]. Pertaining the integration of science learning, recently we are in $21^{\text {st }}$ century and it demands all the skills that can solve the global problem.

The problem or issues that happened recently similar with sosioscientific issues and need a complex design solution which is technology involved. The problems also needed an innovation of integration between technology, engineering, mathematic, and science. So, over the decade the notions of developing learning strategies to accept global demand in revolution industry 4.0. skills that using technologies as a tools to overcome the current issues, developed countries such as US, Europe, Japan, construct STEM on science teaching [3][4].
STEM education has already evolved to metadiscipline that become international topic to discuss [2]. It removes the traditional barriers of teaching learning in science that separates the subjects to become integration learning. STEM refers to integrating between science, technology, engineering, and mathematics all over grades and students from pre-school until post-doctoral program and in informal also formal education. It is applied in order to they can face the work life and solve the global issues in this [5]. STEM brings the two concepts together of learning science through those four disciplines. There is scientific inquiry that contain the formulation of a question that can be answered by the investigation, while engineering design contain formulation of the problem that can be solved by constructing and evaluating during the post design [2].

The purposes of STEM education especially in science learning are to motivate students in order to practice using integrated skills to solve problems and become meaningful learning [6][7][8]. STEM also can develop students as innovator, inventor, logical thinker, independent, and someone who capable of using technology in their life [9] The other purposes is to develop STEM-literate society, it means that in this century, the students need to be future citizens to apply knowledge from STEM discipline in real life [4][2]. This can be named as STEM literacy. 
STEM literacy can be defined as an ability to identify, apply, and to integrate the concept of science, technology, engineering, and mathematics to innovate and solve the complex problem [10]. STEM literacy refers to knowledges, attitudes, understanding of the characteristic or STEM, Awareness of how STEM discipline, and willingness to engage in STEM-related issues [11]. STEM literacy driven the literacy from each subject that combined in STEM. Scientific literacy can be defining the understanding of science concept and process. Technology literacy is understanding, evaluate the technology principle and strategies that needed to solve the problem. Engineering literacy as understanding of how the technology develop through engineering design. Mathematic literacy the capacity to identify, understand, and engaged the role of mathematics in private life, occupational life, and social life [12].

STEM literacy of students can be reached by the process of learning using project [4][13]. The project is emphasised to engineering design that can make a student reach their creativity [14][15][16]. The students are received the task to solve some problem pertaining the integration of concept science, engineering, technology, and mathematics. The project-based learning collaborated with STEM learning can promote students higher order thinking to design the problem solving for the issues that they faced to solve. Decision making are really important to build the project. Project based-learning with STEM education also can develop students learning competences [17], students' attitude [18][19], science process skill [20][21], and effective learning [22]

In the process of learning science with project, somehow students show their own performance. The results of project-based learning pointing the different result of performing based on gender differences. The boys can show they best performance at mathematics, engineering, and computation [23]. While girls show their best performance at arts, science, technology. and memories but not good enough in technical material [24].

So that, this article would analyse the students STEM literacy through project-based and STEM learning based on gender differences in science learning.

\section{RESEARCH METHOD}

This research is used descriptive method. The subject in this research is the student's preservice teacher of science and biology education study program for about 21 students with 4 boys and 17 girls in the second semester of the freshmen. The research is conducted in basic physic laboratory. The laboratory activity is using STEM approach with project. The students are divided into 4 groups and each group consist of boy's students. The project that is given to students are "Sailor boat" and "Let's fun with music". Both of project ask students to make a prototype of boat and music instrument by their own idea. Each project is conducted for 3 meetings (designing, making, and testing). The stages of this learning is used modified design learning with project from The Steps of Engineering Design Process [25] such as:

Table 1

Description Of Learning Stages

\begin{tabular}{|c|c|c|}
\hline Stages & Description & Aspect \\
\hline \multirow[t]{4}{*}{ Designing } & $\begin{array}{l}\text { Students design the prototype (project) based } \\
\text { on science concept from each problem }\end{array}$ & Science \\
\hline & $\begin{array}{l}\text { Students design the prototype (project) with } \\
\text { consideration of how to construct the } \\
\text { prototype, what material that is used? why we } \\
\text { use those material? }\end{array}$ & Engineering \\
\hline & $\begin{array}{l}\text { Students design the prototype (project) with } \\
\text { consideration of what tools and the technique } \\
\text { to construct the prototype? The modern one or } \\
\text { the traditional one? }\end{array}$ & Technology \\
\hline & $\begin{array}{l}\text { Students design the prototype (project) with } \\
\text { consideration the size, length, calculations to } \\
\text { make it perfect and useful project }\end{array}$ & Mathematics \\
\hline Presentation & $\begin{array}{l}\text { Students present their design in front of their } \\
\text { friends and receive the advice, so that they can } \\
\text { revise the design before they construct. }\end{array}$ & \\
\hline \multirow[t]{2}{*}{ Making } & $\begin{array}{l}\text { Students construct the prototype from each } \\
\text { problem using the material that has been } \\
\text { decided and calculated. }\end{array}$ & Engineering \\
\hline & $\begin{array}{l}\text { Students construct the prototype from each } \\
\text { problem using the technique that has been } \\
\text { decided and calculated. }\end{array}$ & Technology \\
\hline $\begin{array}{l}\text { Testing and } \\
\text { Communicating }\end{array}$ & $\begin{array}{l}\text { Students demonstrate the prototype in front of } \\
\text { their friends. }\end{array}$ & \\
\hline
\end{tabular}

The research instrument to take the data that is used are observation sheet for student's performance in laboratory activity and questionnaire of students for their laboratory activity per-aspect that describes their competences in science, technology, engineering, and mathematics. The technique to take the data that is used in this research are video recording, observation, and informal interview.

\section{RESULT AND DISCUSSION}

The results of this research pertaining students' STEM literacy based on Gender differences in science learning are depend on the results of student's performance in basic physic laboratory with two sub-themes about Archimedes law and Waves and Sound project.

The first laboratory activity is talked about Archimedes law with "Sailor Boat" project. In this project, students are asked to design the boat that can be load difference liquid with different density. The boat which can sail and load those liquid in container. They can design, considering all the tools, substances, and technique in specific worksheet that has been given in the first week. After that, in second week, they can construct the boat based on their design in the first week. Next, the third week they can test the boat. It will sail and carry the liquid container properly or not. The students also asked to measure the level of water in boat when it carries different liquid. So, they can conclude the results and relate it with Archimedes Law about density.

Second laboratory activity is talked about Waves and Sounds with "Let's Fun with Music" project. This project, students asked to design their music instrumental that can be applied together like percussion. They have to understand 
first about relation of frequency, amplitude, timbre, and the material of things that is used as instrument. So, the students can decide what tools and material which can they use.

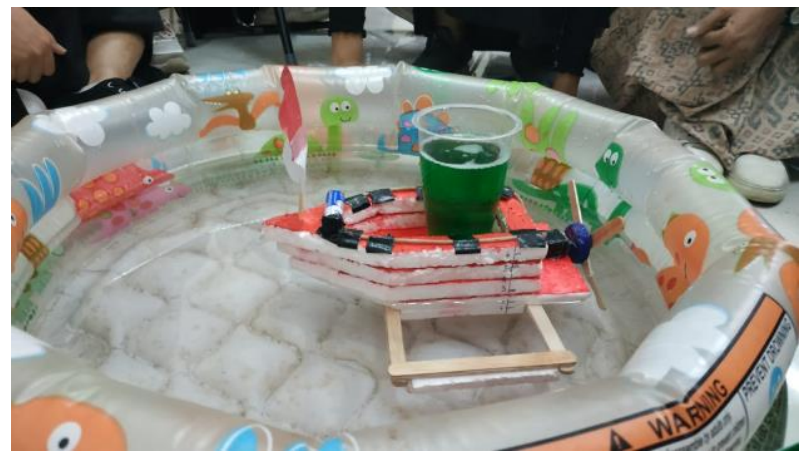

Fig. 1 The Sample of Test Activity in Sailor Boat Project.

Then, they have to measure the tone of music calibrate with the application in Google Play named Da Tunes. Students can know what tunes that is produced by their instrument material. Second week, students construct the music instrumental and make sure those are have been calibrated with the Da Tunes application in order it has their tunes.

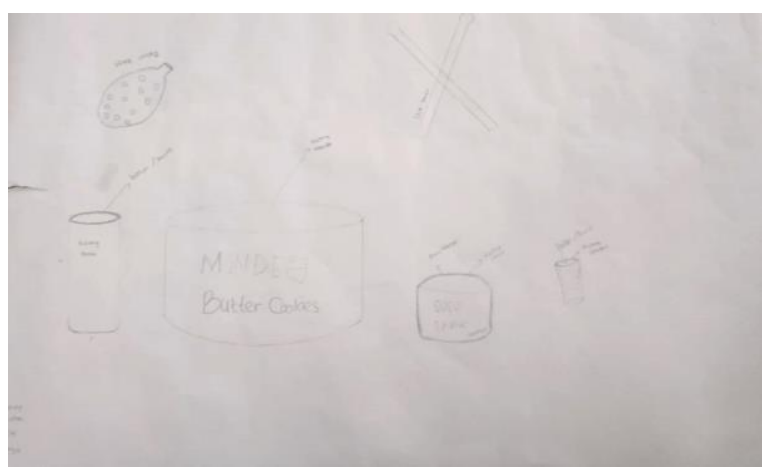

Fig. 2 The Sample of Designing Activity in Let's Fun with Music Project.

In this construct activity, there are groups that provide the instrumental music from plastic, can, glass bottle, and etc. All of the instrumental music are collected from waste product. Then, they have to decided what song that will they perform next week based on their instrumental music. The final week of laboratory activity, students are asked to perform as a band with different song for each group. Most of them choose the pop and up beat music such as Kisah Klasik untuk Masa Depan, Yamko Rambe Yamko, Buka Semangat Baru, and Jadikanlah Aku Pacarmu.

Students do the project in groups and each group consist of boys and girls. So, in the activity those are students have different characteristic, easiness, and difficulty to figure out the project. Pertaining the STEM literacy of students after the project and scored during the project have different result between boys and girls. The results are shown as graph below briefly.

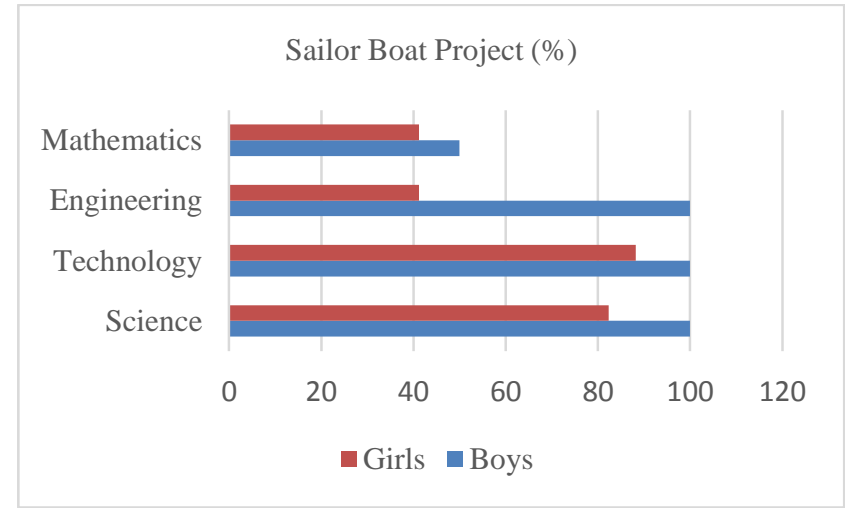

Fig. 3 The Result Percentages of Student's STEM Literacy in Sailor Boat Project.

From this result above, it shows that boys and girls have different result in STEM literacy that brief as science, technology, engineering, and mathematics. Boys got the higher results percentages performance in science, technology, and engineering. Meanwhile, girls got the higher percentages performance in technology and the second one in science. Nevertheless, the lowest percentages performance of boys is mathematics. Similar with boys, girls also got the lowest percentages performance in mathematics and additional in engineering. This result is only from one project in laboratory activity. The other one can be shown as data bellow.

\section{Let's Fun with Music (\%)}

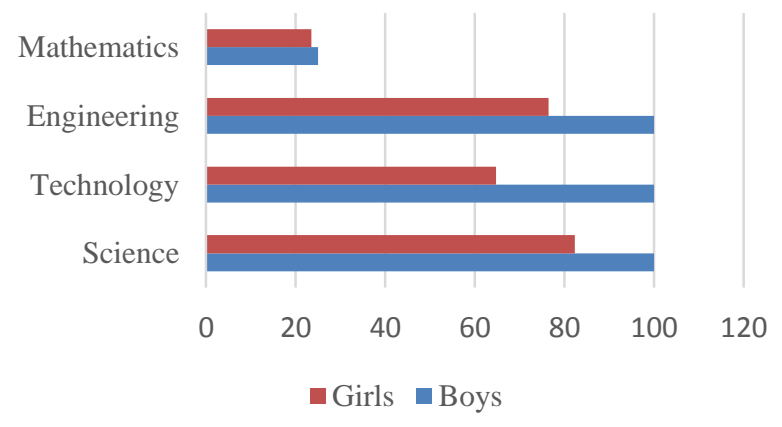

Fig. 4 The Result Percentages of Student's STEM Literacy in Let's Fun with Music Project.

From this result above, it shows that boys and girls have different result in STEM literacy that brief as science, technology, engineering, and mathematics. Boys got the higher results percentages performance in science, technology, and engineering. Meanwhile, girls got the higher percentages performance in engineering and the second one in science. Nevertheless, the lowest percentages performance of boys is mathematics. Similar with boys, girls also got the lowest percentages performance in mathematics and additional in engineering. Boys result nearly the same with sailor boat project, while girls' results have differences in engineering and technology result. It is caused some factor that make the result as shown in graph. From the survey in 
questionnaire, girls more like doing the second project (Let's Fun with Music) rather than the first one with the result $88 \%$. Likewise, the girls, Boys prefer the first project (Sailor Boat) rather than the second one with the result $75 \%$.

From both performance project results in STEM literacy, boys have outperformed than the girls in all aspect. It can be reviewed from STEM generation and has a boarder meaning fit includes environment, economic, education, medicine, and industrial and tends to logic, calculation, prediction, hard skill that students must have in this global era industry revolution 4.0 [12]. So, it can't be argued that boys have outperformed in STEM literacy result than the girls. The same result shown by [24] boys takes more in STEM major rather that girls, and boys is outperformed in concrete material (i.e., fact, data) and abstract material (i.e., concept, theories). But, in hands-on material (i.e., experiment) boys and girls has not big differences, they quite similar. So, when this research result shows girls in first project has higher percentage in technology and the second project is engineering. Similar results with [26] that boys have higher performance in STEM than girls.

This research results shows the differences of STEM literacy between boys and girls in every singe aspect. Although the girls reach higher percentages result in on of the aspect for instance science, technology, and engineering, the score is not higher than the boys. It can be caused not only from their attitude or habituation in learning or learning style, but also from their human body anatomy is already different. For instance, boys have dominant in left hemisphere of his brain [27]. The left hemisphere of brain has the characteristic i.e. reading, writing, calculating, using logic, mathematics, and using more fact. While the girls are different with boys, they have dominant in right hemisphere of his brain which has the characteristic such as imagination, searching the idea, love the arts, creativity, and intuition. Based on that discussion, that is the reason that the boys are outperformed in engineering with the activity construction and designing, science with the activity relate the theory with the project that pertaining their living life problems.

From the secondary result of this research, it is correlated with that discussion, girls with $94 \%$ are like to decorate the boat activity rather than calculate and make comparison in measurement for making boat in sailor boat project, also they more like decide the song that will they do in performance activity in let's fun with music project rather than calibrate the instrumental music with $\mathrm{Da}$ Tunes application for make a tune. So, it is also strengthening the results that boys more like sailor boat project rather than let's fun with music project, likewise the girl's preferences. It is caused that sailor boat project contains more calculation, logic, comparison in math rather than in let's fun with music project that contain more arts activity and not to difficult to construct the instrumental music because it is taken from waste material. And also this research is conducted in basic physics laboratory activity, so it can be driven as an attitude toward learning STEM in Physics has different result between boys and girls, that the result shows boys more active, interest, and passionate than girls. Similar with the research result [27] that boys have more interest than girls in physics classes.

Technology aspect in STEM literacy results shows that girls also reach the higher percentages and also the boys in sailor boat project. They are the gen $\mathrm{Z}$ that have already familiar and skilled to use technology, to decided what tools and material that suitable with the project. But, in let's fun with music girls in technology aspect reach not more than the sailor boat project. It can be caused, most of them sometimes do not know how to operate the Da Tunes application. Sometimes they afraid to make mistake in application [27] when they face the devices.

The last aspect is mathematics, that shows the anomaly results from both of project and both of students, boys and girls reach the lowest score in this aspect. Even the boys said that more skilled in mathematics, but in this case, they reach the lowest score in this aspect. It can be caused boys still confuse in calculation and making comparison of boat and determine the tune for instrumental music. They lack of habituation to do learning based on project like this research. Also, the girls can be driven lack of confident in calculation. Several studies found that girls are less confident than males in mathematics [28].

\section{CONCLUSIONS}

The research can be concluded that student's STEM literacy result has different based on the gender differences. In the first project, sailor boat, boys reach the higher percentages in aspect science, engineering, and technology, while girls reach the higher percentages in science and technology. The second project, let's fun with music, boys reach the higher percentages in aspect science, engineering, and technology, while girls reach the higher percentages in science and engineering. In both of project, boys and girls reach the lowest percentages in mathematics aspect. From whole results, can be said that boys are outperformed than girls in STEM literacy in science learning especially in basic physics laboratory activity.

\section{REFERENCES}

[1] Ratelle, C.F., Larose, S., Guay, F., \& Senécal, C. 2005. Perceptions of parental involvement and support as predictors of college students' persistence in a science curriculum. Journal of Family Psychology, 19(2), 286-293.. 19.2.286.

[2] Kennedy, T,J. and Odell, M, R,L. 2014. Engaging Students in STEM Education. Science Education International. 25 (3). 246-258.

[3] Joyce, A. \& Dzoga, M.2011. Science, technology, engineering and mathematics education: Overcoming challenges in Europe. Intel Educator Academy EMEA.

[4] Tati, T, Firman, H, and Riandi, R. 2017. The Effect of STEM Learning Through The Project of Designing Boat Model Toward Student STEM Literacy. 
International Conference on Mathematics and Science Education. 2-8. doi :10.1088/17426596/895/1/012157

[5] Gonzalez, H.B. \& Kuenzi J. 2012. Congressional Research Service Science, Technology, Engineering, and Mathematics (STEM) Education:A Primer, p. 2. Retrieved: http://www.stemedcoalition.org/wp-cont ent/uploads/2010/05/STEM-Education-Primer.pdf.

[6] Wai, J., Lubinski, D., Benbow, C. P., \& Steiger, J. H. 2010. Accomplishment in Science, Technology, Engineering, and Mathematics (STEM) and Its Relation to STEM Educational Dose: A 25-Year Longitudinal Study. Journal of Educational Psychology, 102(4), 860-871. Retrieved from EBSCOhost.

[7] Leon, J, Nunez, J, L., and Liew, J. 2015. Selfdetermination and STEM Education: Effect of Autonomy, Motivation, and Self-regulated Learning on High School Math Achievement. Learning and Individual Differences. Retrieved: journal homepage: www.elsevier.com/locate/lindif.

[8] Moore TJ.; Glancy AW.; Tank, KM, Kersten, JA, Smith KA, and Stohlmann MS. 2014. A framework for quality $k-12$ engineering education: Research and development. (J-PEER), 4 (2). "PDCA12-70 data sheet," Opto Speed SA, Mezzovico, Switzerland.

[9] Stohlmann, M.; Moore, T. J.; \& Roehrig, G. H. 2012. Considerations for Teaching Integrated STEM Education. Journal of Pre-College Engineering Education Research (J-PEER), 2 (1), 4.

[10] Balka, D.2011.Standards of mathematical practice and STEM, Math-science connector newsletter. School Science and Mathematics Association. pp 6-7.

[11] Bybee.2010. What is STEM Education?.Science.329. www.sciencemag.org.

[12] Zolman, A. 2012. Learning for STEM Literacy: STEM Literacy for Learning. School Science and Mathematics. 112 (1).12-19.

[13] Aninda, A, Permanasari, A, and Ardianto, D. 2019. Implementasi Pembelajaran Berbasis Proyek Pada Materi Pencemaran Lingkungan untuk Meningkatkan Literasi STEM Siswa SMA. Journal of Science Education and Practice. 3 (2). 1-16.

[14] Sookpatdhe T and Soranastaporn S 2016 Simulation and Project Based Learning for Developing Creativity: From Classroom to Real Life TSJLD 1 (1) pp $85-105$

[15] Munakata M and Vaidya A 2015 Using Project- and Theme-Based Learning to Encourage Creativity in Science Journal of College Science Teaching 45 (2) pp 48-53.

[16] Ergül N R and Kargin E K 2014 The Effect Of Project-Based Learning On Students' Science Success. Procedia - Social and Behavioral Sciences 136 pp $537-541$
[17] Baran, M. \& Maskan, A. 2010. The Effect of ProjectBased Learning On Pre- Service Physics Teachers' Electrostatic Achievements. Cypriot Journal of Educational Sciences , 5, 243-257

[18] K1lınç, A. 2010. Can Project-Based Learning Close the Gap?. Turkish Student Teachers and Proenvironmental Behaviours. International Journal of Environmental \& Science Education, 5, 495-509.

[19] Tseng, et al. 2013. Attitudes Towards Science, Technology, Engineering and Mathematics (STEM) in a Project Based Learning (PjBL) Environment. International Journal Technology and Design Education, 23, 87-102.

[20] Özer, D., Z., \& Özkan, M. 2012. The Effect of the Project Based Learning on the Science Process Skills of the Prospective Teachers of Science. Journal of Turkish Science Education, 9 (3), 131-136.

[21] Septiani, A. and Rustaman, N, Y. 2017. Implementation of Performance Assessment in STEM (Science, Technology, Engineering, Mathematics) Education to Detect Science Process Skill. Journal of Physics: Conference Series. doi:10.1088/17426596/812/1/012052.

[22] Cook. 2012. Preparing Biology Teachers to Teach Evolution in a Project-Based Approach. Winter, 21 (2). $18-30$

[23] Hyde, S, J. and Mertz, J, E. 2009. Gender, Culture, and Mathematics Performance. PNAS. 106 (22). 8801-8807.

[24] Konak, S, K., D’Allegro, M, L., and Dickinson, S. 2011. Review of Gender Differences in Learning Styles: Suggestion for STEM Education. Contemporary Issues in Education Research. 4 (3). 918

[25] Hynes, M., Portsmore, M., Dare, E., Milto, E., Rogers, C., Hammer, D. and Carberry, A. 2011. Infusing Engineering Design into High School STEM Courses. Retrieved from http://ncete.org/flash/pdfs/Infus ing \%20Engineering\%20Hynes.pdf

[26] Ganley, M , C. and Vasilyeva, M. 2011. Sex Differences in The Relation Between Math Performance, Spatial Skills, and Attitudes. Journal of Applied Developmental Psychology. 32. 235-242.

[27] Nurramadhani, A, Utari, S., and Widodo, A. 2013. Gender Differences and Junior High School Students Conceptual mastery by Using Virtual Laboratory Media on Optic Topics. Proceeding of International Seminar on Mathematics, Science, and Computer Science Education. 11-16.

[28] Hyde, J. S., Lindberg, S.M., Linn, M. C., Ellis, A. B., \&Williams, C. C. 2008. Gender Similarities Characterize Math Performance. Science, 321, 494495. 